\title{
The use of formaldehyde for the disinfection of maternally incubated eggs of noble crayfish (Astacus astacus)
}

\author{
Benedetto Sicuro (1)
}

Received: 19 July 2016/Accepted: 22 October 2016/Published online: 31 October 2016

(C) The Author(s) 2016. This article is published with open access at Springerlink.com

\begin{abstract}
The high mortality of maternally incubated eggs represents a serious problem that prevents the development of noble crayfish (Astacus astacus) farming in Italy. In this experiment, formaldehyde bath technique has been tested with maternally incubating females. The survival rate of maternally incubated eggs, exposed to progressively reduced concentrations of formaldehyde $(4000,3000,2000,1000,1500$ and $500 \mathrm{mg}^{-1}$ ), has been compared with that of untreated controls for two consecutive years (2010 and 2011). The formaldehyde treatments were administered as disinfection baths, for a period of $15 \mathrm{~min}$, twice a week. A concentration of formaldehyde of $500 \mathrm{mg} 1^{-1}$, or greater, was found to be effective in controlling egg mortality, without apparent harming the female broods.
\end{abstract}

Keywords Crayfish farming $\cdot$ Disinfection $\cdot$ Antifungal treatment $\cdot$ Oomycetes $\cdot$ Branchiobdellid

\section{Introduction}

In Italy, crayfish farming is principally based on a few extensive family managed farms (Quaglio et al. 2008). At the moment, crayfish production is somewhat limited, with a production of 4.1 tons in 2009, which was principally represented by the red swamp crayfish (Procambarus clarkii) (AA.VV 2011). One of the main problems for European native crayfish farming is the spread of alien crayfish species originating from North America (Kozubíkova et al. 2008; Kouba et al. 2014), which often carries crayfish plague pathogens, oomycete Aphanomyces astaci (Adelrman 1996; Hirsch et al. 2008; Aquiloni et al. 2010; Coignet et al. 2012). The most valuable crayfish species for European aquaculture is the noble crayfish (Astacus astacus), which can reach prices of 60-80 $€ \mathrm{~kg}^{-1}$ (Bohman and Edsman 2011; Gherardi 2011) with a European production of 41 tons in 2011 (FAOSTAT 2013). The main crayfish producing countries in Europe are Spain and Italy, where 1509 tons of red swamp crayfish were produced in 2010 (Vedia and Miranda 2013). The main problem of crayfish rearing in Italy is the high incidence of aquatic mycosis during egg incubation, which has two main consequences: the hampering of the diffusion of crayfish farming and the increasing environmental impact of crayfish farms. Dead eggs can be invaded by aquatic fungi, e.g., Saprolegnia sp. and other oomycetes, which often spread to the surrounding eggs, and may result in 100\% mortality in the worst cases (Edgerton et al. 2002; Kouba et al. 2013). The diffusion of this mycosis takes on an important ecological relevance as the disinfectants used in rearing conditions can contaminate output waters and the farms can also become direct vectors of disease in natural ecosystems. This fungal disease is usually controlled by manually removing dead

B. Sicuro $(\square)$

Department of Veterinary Sciences, University of Torino, L. go Braccini, 2, 10095 Grugliasco, TO, Italy

e-mail: benedetto.sicuro@unito.it 
eggs, the application of antifungal treatments, or a combination of both (Lilley and Inglis 1997; Policar et al. 2006, 2011; Kouba et al. 2010). Many disinfectants have already been tested for the treatment of artificially incubated crayfish eggs in experimental conditions (González et al. 2009). Formaldehyde, an alternative to malachite green, has been found to be the most effective for signal (Pacifastacus leniusculus) and noble crayfish (Sáez-Royuela et al. 2009; Kouba et al. 2010). Considering that maternal incubation is usually adopted in Italy, the aim of this work was to evaluate the disinfection efficacy of a formaldehyde bath on maternally incubated noble crayfish eggs.

\section{Materials and methods}

\section{Experimentation site}

This research was carried out on a crayfish farm in Northwest Italy, in Crava (Cuneo province). The farm utilizes a freshwater spring source (conductivity $5.0 \pm 0.7 \mu \mathrm{S} \mathrm{cm}^{-1} ; \mathrm{pH} \quad 7.1 \pm 1.0 ;$ nitrites $0.01 \pm 0.0 \mathrm{mg}^{-1}$; nitrates $12.5 \pm 10.6 \mathrm{mg} \mathrm{l}^{-1}$ ) situated near the farm in an area where white-clawed crayfish (Austropotamobius pallipes) are naturally present. Based on previous observations on the farm, this study was focused on noble crayfish (Astacus astacus) egg incubation and disinfection, from December to February, as this is the most critical phase in two consecutive years.

Experimental plan

During first year, the experimentation was started on December 10th 2009 and finished on February 29th 2010. During the first week, the crayfish were acclimatized to the experimental conditions and then the disinfection protocol was started. The experimental plan was monofactorial and balanced, the experimental factor tested was the disinfection, and four levels and four replicates $(4 \times 4)$ were adopted. Eighty similar-sized adult females (average body weight $46.8 \pm 2.5 \mathrm{~g}$ and length $11.2 \pm 1.9 \mathrm{~cm}$ ) with approximately $80-120$ eggs were selected from the farm, and five females were randomly allotted to each of the 16 tanks (volume 250 1; water flow $6.5 \mathrm{l} \mathrm{min}^{-1}$ ). This density is commonly applied in rearing conditions (3-4 crayfish $\mathrm{m}^{-2}$ ). Sand, stones, aquatic plants and natural material were introduced into the bottom of the tanks to provide comparable farming conditions to natural ones. Similar formaldehyde (utilized as Sigma/Aldrich 37\% formalin) concentrations to those previously recommended by Kouba et al. (2010), that is, 2000, 3000 and $4000 \mathrm{mg}^{-1}$, were compared with a chemically untreated control. The disinfection process consisted in transferring gravid females to separate containers ( 41 of volume) for a 15 min disinfection bath, two times per week. Before the disinfection bath, the crayfish were all checked weekly for any eventual dead eggs. During the second year, the experiment was started on November 10th 2010 and finished on February 24th 2011. During the first week, all the tanks were stocked with crayfish, which were allowed to adapt to the experimental conditions. The experimental design was similar to the previous year. Ninety-six females (body weight $72.0 \pm 5.3 \mathrm{~g}$, total length $13.0 \pm 2.1 \mathrm{~cm}$ ) were selected from the farm and randomly placed into 16 tanks (water flow $5.51 \mathrm{~min}^{-1}$ ), six crayfish per tank. Considering the results obtained from the previous year, three concentrations of formaldehyde $\left(500,1000\right.$, and $\left.1500 \mathrm{mg}^{-1}\right)$, were compared against an untreated control group. All the females were checked weekly and any dead eggs or infested by fungal infection were removed from the experimental groups. The water temperature and dissolved oxygen levels were monitored weekly $\left(7.0 \pm 1.5^{\circ} \mathrm{C}\right.$ and $10.0 \pm 1.1 \mathrm{mg} \mathrm{l}^{-1}$ in 2010 and $8.1 \pm 2{ }^{\circ} \mathrm{C}$ and $8.0 \pm 2.3 \mathrm{mg} \mathrm{l}^{-1}$ in 2011), respectively. The presence of ectoparasites on crayfish carapace was already noticed in the first weeks of the experimentation in 2009, and their numbers were subsequently counted twice a week in the final part of the experiment in the 2009-2010 season. In the 2010-2011 season, branchiobdellids were counted weekly on all the crayfish, and their presence was compared with that of the experimental groups. The presence of ectoparasites was also monitored at the end of both experiments, by means of a visual inspection. 
Statistical analysis

For the statistical analysis of the egg mortality data, normality of data was tested with the "Theoretical quantiles" (Venables and Ripley 2002) test. The data were then analyzed by means of the Kruskal-Wallis test and the Tukey's test for multiple comparisons of the means, using $\mathrm{R}$ software (R version 2.5.0, 2007-04-23). The response variable was the number of dead eggs in each experimental treatment.

\section{Results}

The effect of disinfection in 2010 was clearly positive, and the difference between the disinfected groups and the control was significant (Fig. 1), although there were no differences between the three formaldehyde concentration treatments at the end of the experiment (Table 1). In general, egg mortality was very low with some tanks containing disinfected females with no apparent egg mortality. During the second year, the disinfectant doses were reduced, and positive results were again obtained, regardless of the formaldehyde concentration (Fig. 2; Table 2), thus showing the positive effect of the disinfectant. Moreover, considering the time trend of the egg mortality (Figs. 1,2), a maximum egg mortality peak was clearly visible during the third week of the experimentation, after which the eggs reached a steady state condition without any substantial mortalities. This peak was more evident in the control group in both experiments. At the end of this experimentation, the effect of disinfection was confirmed by the almost complete absence of branchiobdellids on the crayfish and disinfected egg. During the 2010-2011 season, these annelids were classified as Branchiobdella parasita, belonging to the Branchiobdellidae family. A significant reduction in the number of branchiobdellid parasites was observed between the controls and females treated with the formaldehyde bath treatments. The number of parasites did not differ significantly among the formaldehyde treated groups, but tended to be lower at higher concentrations (Fig. 3).

\section{Discussion}

Artificial incubation has been suggested as a possible method for the intensification of crayfish farming (Carral et al. 1992; Henryon and Purvis 2000; Leonard et al. 2001), but the level of this aquaculture activity is rather underdeveloped in Italy, and maternal incubation is still commonly used. Until now, the best results among the disinfectants that are normally used have been obtained with formaldehyde concentrations of between 2500 and $4500 \mathrm{mg}^{-1}$, for treatments of $15 \mathrm{~min}$ on alternate days or three times a week (Celada et al. 2004; Melendre et al. 2006; Sáez-Royuela et al. 2009; Kouba et al. 2010). Moreover, a great egg survival was only

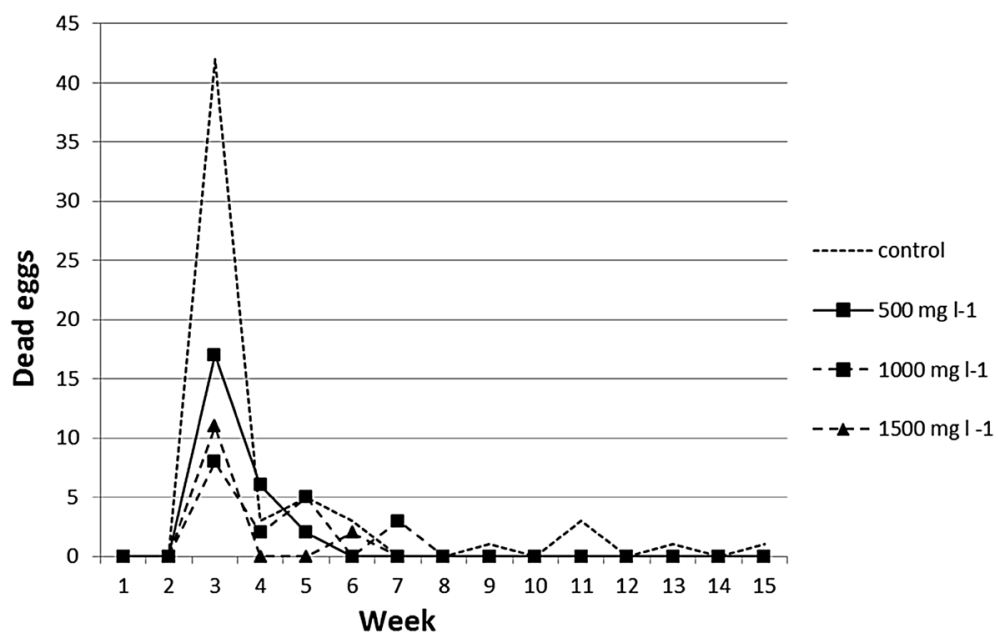

Fig. 1 Time trend of the noble crayfish (Astacus astacus) egg mortality, in the 2009-2010 season 
Table 1 Comparison of the number of dead eggs of noble crayfish (Astacus astacus) at the end of the experiment in the 2009-2010 season

\begin{tabular}{lr}
\hline Experimental treatment & Dead eggs \\
\hline Control & $3.5 \pm 3.0^{\mathrm{a}}$ \\
$2000 \mathrm{mg} \mathrm{l}^{-1}$ & $0.25 \pm 0.5^{\mathrm{b}}$ \\
$3000 \mathrm{mg} \mathrm{l}^{-1}$ & $0.75 \pm 1.5^{\mathrm{b}}$ \\
$4000 \mathrm{mg} \mathrm{l}^{-1}$ & $0.75 \pm 1.0^{\mathrm{b}}$ \\
\hline
\end{tabular}

Mean $\pm \mathrm{SD}, n=4$

Values with differing letters are significantly different $(P<0.05)$

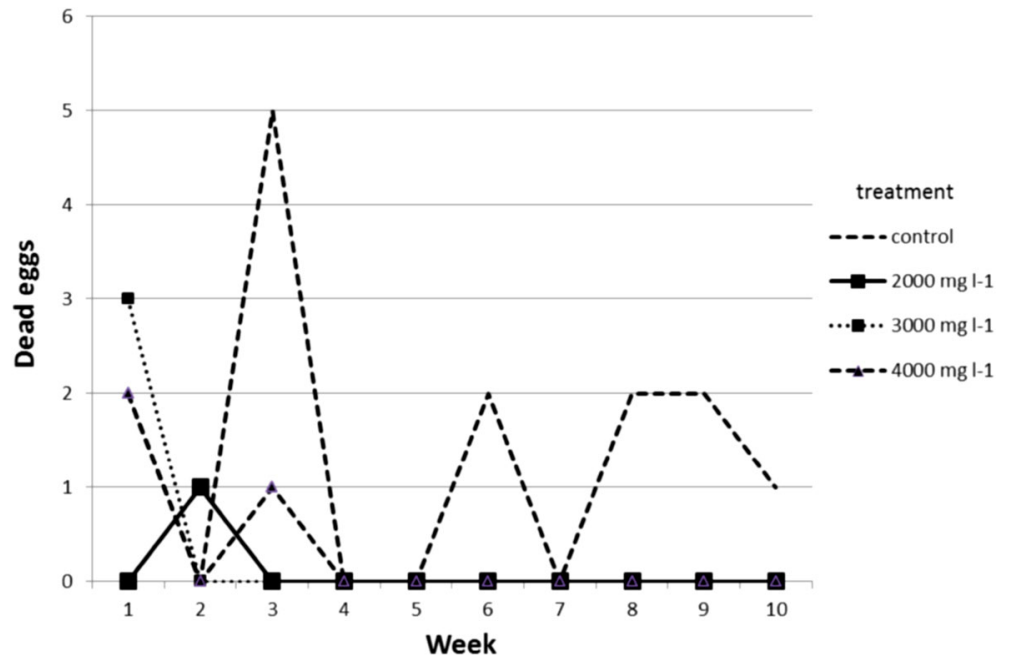

Fig. 2 Time trend of noble crayfish (Astacus astacus) egg mortality, in the 2010-2011 season

Table 2 Comparison of the number of dead eggs of noble crayfish (Astacus astacus) at the end of the experiment in the 2010-2011 season

\begin{tabular}{lr}
\hline Experimental treatment & Dead eggs \\
\hline Control & $2.3 \pm 4.7^{\mathrm{a}}$ \\
$500 \mathrm{mg} \mathrm{l}^{-1}$ & $1.0 \pm 2.4^{\mathrm{b}}$ \\
$1000 \mathrm{mg} \mathrm{l}^{-1}$ & $0.7 \pm 1.4^{\mathrm{b}}$ \\
$1500 \mathrm{mg} \mathrm{l}^{-1}$ & $0.5 \pm 1.7^{\mathrm{b}}$ \\
\hline
\end{tabular}

Mean $\pm \mathrm{SD}, n=4$

Values with differing letters are significantly different $(P<0.05)$

obtained only by removing any dead eggs during incubation (Policar et al. 2006; 2011) or when a microplate was used in a Japanese crayfish Cambaroides japonicus culture (Nakata et al. 2004). However, considering that these methods are labor intensive, the use of a disinfectant can be considered beneficial in terms of labor reduction. The concentration of formaldehyde $\left(2000 \mathrm{mg}^{-1}\right)$ used in our experiment in the 2009-2010 season was comparable with that of reference studies. In the 2010-2011 season, the concentration of formaldehyde was reduced even further, and it was still effective at $500 \mathrm{mg} \mathrm{l}^{-1}$. This value is 5-6 times lower than that used in the past, and the disinfectant was administered twice a week, not on alternate days or three times a week as in previous studies (Celada et al. 2004; Sáez-Royuela et al. 2009; Kouba et al. 2010). Moreover, the adoption of a disinfection bath, which has already been used successfully in noble crayfish (Policar et al. 2006; Kouba et al. 2013), has almost completely solved the problem of the environmental impact of the use of disinfectants. In fact, the use of separate tanks for disinfection reduces the quantity of treated water to a great extent (tank 


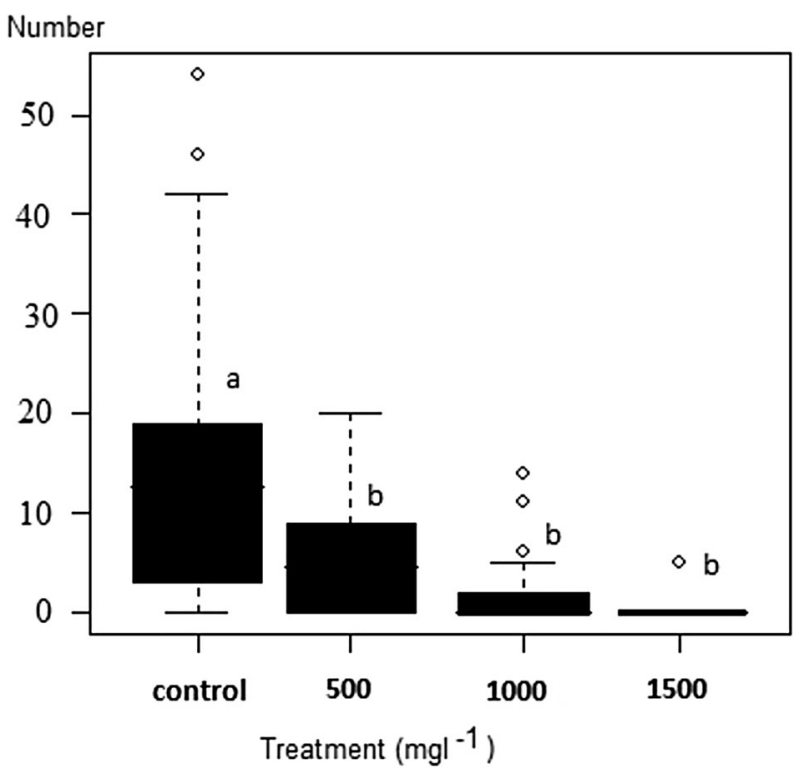

Fig. 3 Branchiobdellids incidence at the end of the experiment in the 2010-2011 season

volume of 4 1) and facilitates the separate management of treated water, thus avoiding its release into natural water bodies. In Italy, a great deal of attention has been paid to the reintroduction of white-clawed crayfish (Nardi et al. 2005) and several LIFE projects, funded by the EU, are focused on this species (e.g., http://www. lifecrainat.eu/en/). The disinfection method proposed here shows the potential for efficacious application to this species. In 2009, an event of crayfish plague infection, a disease caused by the fungus-like organism Aphanomyces astaci, completely decimated the crayfish on the farm where the experimentation was conducted. This event increased attention toward the risk of future fungal infection. In light of these considerations, the reintroduction of formaldehyde into crayfish farming through the present suggested methods could be hypothesized. Moreover, it should be recalled that formaldehyde can be used as tank disinfectant on trout farms in Italy, and this fact makes the control of its illegal use during incubation difficult. Another promising alternative treatment against both fungal infections of eggs and the transfer of a crayfish plague pathogen is peracetic acid (Jussila et al. 2011, 2014; Kouba et al. 2012) that has been recently found also effective in signal crayfish (Chupani et al. 2016). More research is needed for this chemical compound concerning the time trend of egg mortality, environmental contamination and the occurrence of branchiobdellids. The principal difference between the two successive years was the low number of infected eggs during first year, in all the treatments. This was likely due to the fact that the experimental tanks were utilized for the first time during the 2009-2010 season, while a general increase in aquatic mycetes was evident during the 2010-2011 season, regardless of the experimental treatment. Therefore, it is important not only to disinfect crayfish, but also the tank environment on the farm to reduce and minimize the occurrence and diffusion of mycetes. Considering the egg mortality time trend on the farm, the increased occurrence of fungal infection was only evident in the first 4 weeks of incubation in both seasons, and a small mortality peak was observed for the third week of egg incubation, in particular for the non-disinfected eggs. This is probably related to the immune-competence of the crayfish and to a reduction in the fungal spores and hyphae. Consequently, in the future, the disinfection period could be shortened to the first 4 weeks of incubation, and in this way a further decrease in the environmental impact would be obtained. A small increase in the disinfectant dosage is also advisable during the first week of incubation. However, Kouba et al. (2013) suggested that if a chemical treatment is applied once, it should be followed by regular chemical baths to prevent uncontrollable microbial recolonization. They also pointed out that the nature of the normal microflora on the surface of crayfish eggs is still poorly understood. The effect of the occurrence of branchiobdellids on the biological cycle of crayfish is still not clear. Some authors consider them commensals more than ectoparasites (Gelder 1999; Edgerton et al. 2002; Oberkofler et al. 2002; Quaglio et al. 2006), and their association with crayfish has recently been indicated as a cleaning symbiosis, that is, an intermediate interaction between mutualism and parasitism (Brown et al. 2012; 
Farrell et al. 2014). However, the effect of disinfection is much more evident on these invertebrates. The presence of branchiobdellids has already been observed in crayfish in North Italy (Gherardi et al. 2002). During the first year of this study, 15 individuals in the control groups were found with branchiobdellids, but only two were found in the tanks treated with $3000 \mathrm{mg}^{-1}$ of formaldehyde. This formaldehyde treatment was able to reduce but not fully eliminate the parasites. As far as the control treatments are concerned, there was a great increase in branchiobdellids in the 2010-2011 season. This fact confirmed previous considerations on the attention that should be paid to farm environmental contamination and disinfection. It is clear that in Italy and in other European countries where crayfish farming is not very well developed and maternal incubation is still used, an environmental friendly method for disinfection could improve this sector. The introduction of artificial incubation is advisable for the future of crayfish farming in Italy, as highlighted by the Spanish experience (Celada et al. 2004; González et al. 2009). Finally, no apparently negative effect of the disinfection method was observed on the female crayfish, and considering that a formaldehyde concentration of $500 \mathrm{mg}^{-1}$ was found to be effective, this concentration can be recommended for future utilization in crayfish farming.

Acknowledgements I am grateful to Mr. Franco Alberto for allowing me and my students to use his crayfish farm for these experiments. I would also like to thank Prof. Francesco Quaglio for the classification of branchiobdellids. Sincere thanks are also due to Massimo Villa and Enrico Pizzigalli for their support in the field work. I thank Ms. Marguerite Jones for the English revision of the manuscript.

Open Access This article is distributed under the terms of the Creative Commons Attribution 4.0 International License (http:// creativecommons.org/licenses/by/4.0/), which permits unrestricted use, distribution, and reproduction in any medium, provided you give appropriate credit to the original author(s) and the source, provide a link to the Creative Commons license, and indicate if changes were made.

\section{References}

AA.VV (2011) L'acquacoltura. In: Cataudella S, Spagnolo M (eds) Lo stato della pesca e dell'acquacoltura nei mari italiani. Ministry of Agricultural, Food and Forestry Policies (Italy), Rome, pp 322-423 [in Italian]

Adelrman DJ (1996) Geographical spread of bacterial and fungal diseases of crustacean. Revue Scientifique et Technique Office International des Epizooties 15(2):602-632

Aquiloni L, Tricarico E, Gherardi F (2010) Crayfish in Italy: distribution, threats and management. Int Aquat Res 2:143-151

Bohman P, Edsman L (2011) Status, management and conservation of crayfish in Sweden: results and the way forward. Freshw Crayfish 18(1):19-26

Brown BL, Creed RP, Skelton J, Rollins MA, Farrell KJ (2012) The fine line between mutualism and parasitism: complex effects in a cleaning symbiosis demonstrated by multiple field experiments. Oecologia 170:199-207

Carral JM, Celada JD, González J, Gaudioso VR, Fernádez R, López-Baissón C (1992) Artificial incubation of crayfish eggs (Pacifastacus leniusculus Dana) from early stages of embryonic development. Aquaculture 104:261-269

Celada JD, Carral JM, Sàez-Royuela M, Melendre PM, Aguilera A (2004) Effect of different antifungal treatments on artificial incubation of the astacid crayfish (Pacifastacus leniusculus Dana) eggs. Aquaculture 239:249-259

Chupani L, Zuskova E, Stara A, Velisek J, Kouba A (2016) Histological changes and antioxidant enzyme activity in signal crayfish (Pacifastacus leniusculus) associated with sub-acute peracetic acid exposure. Fish Shellfish Immunol 48:190-195

Coignet A, Pinet F, Souty-Grosset C (2012) Estimating population size of the red swamp crayfish (Procambarus clarkii) in fishponds (Brenne, Central France). Knowl Manag Aquat Ecosyst 406:2-10

Edgerton BF, Evans LH, Stephens FJ, Overstreet RM (2002) Synopsis of freshwater crayfish diseases and commensal organisms. Aquaculture 206:57-135

FAOSTAT (2013) (Food and Agriculture Organization of the United Nations) Rome. http://www.fao.org/fishery/statistics/ software/fishstat/en

Farrell KJ, Creed RP, Brown BL (2014) Preventing overexploitation in a mutualism: partner regulation in the crayfishbranchiobdellid symbiosis. Oecologia 174:501-510

Gelder SR (1999) Zoogeography of branchiobdellidans (Annelida) and temnocephalidans (Platyhelminthes) ectosymbiotic on freshwater crustaceans, and their reactions to one another in vitro. Hydrobiologia 406:21-31

Gherardi F (2011) Towards a sustainable human use of freshwater crayfish (Crustacea, Decapoda, Astacidea). Knowl Manag Aquat Ecosyst 401:1-22

Gherardi F, Cenni F, Crudele G, Mori M (2002) Infestation rate of Branchiobdellidis in Austropotamobius pallipes italicus from a stream of central Italy: preliminary results. Bull Fr Pêche Piscic 367:785-792

González R, Celada JD, García V, Gonzaláz A, Carral JM, Sáez-Royuela M (2009) The artificial incubation of crayfish eggs: review and report from an experimental study concerning the effects of offspring origin (maternal or artificial incubation) on the survival and growth of juvenile signal crayfish (Pacifastacus leniusculus, Astacidae). Rev Fish Biol Fisher 19:167-176 
Henryon M, Purvis IW (2000) Eggs and hatchlings of the freshwater crayfish, marron (Cherax tenuimanus), can be successfully incubated artificially. Aquaculture 184:247-254

Hirsch PE, Nechwatal J, Fisher P (2008) A previously undescribed set of Saprolegnia spp. in the invasive spiny-cheek crayfish (Orconectes limosus, Rafinesque). Fund Appl Limnol 172:161-165

Jussila J, Makkonen J, Kokko H (2011) Peracetic acid (PAA) treatment is an effective disinfectant against crayfish plague (Aphanomyces astaci) spores in aquaculture. Aquaculture 320(1):37-42

Jussila J, Toljamo A, Makkonen J, Kukkonen H, Kokko H (2014) Practical disinfection chemicals for fishing and crayfishing gear against crayfish plague transfer. Knowl Manag Aquat Ecosyst 413:2-12

Kouba A, Carral JM, Buřič M, Mráz J, Policar T, Kozák P (2010) Artificial incubation of noble crayfish (Astacus astacus) eggs in a partially recirculating system using formaldehyde as an antifungal treatment. Aquacult Res 41:618-623

Kouba A, Kuklina I, Niksirat H, Máchová J, Kozák P (2012) Tolerance of signal crayfish (Pacifastacus leniusculus) to Persteril 36 supports use of peracetic acid in astaciculture. Aquaculture 350:71-74

Kouba A, Niksirat H, Kuklina I, Buřič M, Kozák P (2013) Ultraviolet light and semi-recirculating systems in artificial incubation of noble crayfish (Astacus astacus) eggs: opportunities and limitations. Aquacult Res 44:67-74

Kouba A, Patrusek A, Kozák P (2014) Continental-wide distribution of crayfish species in Europe: update and maps. Knowl Manag Aquat Ecosyst 413(2):5-12

Kozubíkova E, Petrusek A, Ďuriš Z, Martín MP, Diéguez-Uribeondo J, Oidtmann B (2008) The old menace is back: recent crayfish plague outbreaks in the Czech Republic. Aquaculture 274:208-217

Leonard BV, Lennard WA, Kildea DG (2001) A method for testing the effectiveness of artificial incubation of eggs vs. maternal brooding in the freshwater crayfish Cherax destructor (Decapoda: Parastacidae). Aquaculture 195:299-309

Lilley JH, Inglis V (1997) Comparative effects of various antibiotics, fungicides and disinfectants on Aphanomyces invaders and other saprolegniaceous fungi. Aquacult Res 28:461-469

Melendre JD, Celada JM, Carral M, Sáez-Royuela A, Aguilera A (2006) Effectiveness of antifungal treatments during artificial incubation of the signal crayfish eggs (Pacifastacus leniusculus Dana. Astacidae). Aquaculture 257:257-265

Nakata K, Matsubara H, Goshima S (2004) Artificial incubation of Japanese crayfish (Cambaroides japonicus) eggs by using a simple, easy method with a microplate. Aquaculture 230:273-279

Nardi PA, Bernini F, Bo T, Bonardi A, Fea G, Ghia D, Negri A, Razzetti E, Rossi S, Spairani M (2005) Status of Austropotamobius pallipes complex in the watercourses of the Alessandria province (N-W Italy). Bull Fr Pêche Piscic 376:585-598

Oberkofler B, Quaglio F, Furder L, Fioravanti ML, Giannetto S, Morolli C, Minelli G (2002) Species of Branchiobdellidae (Anellidae) on freshwater crayfish in South Tyrol (Northern Italy). Bull Fr Pêche Piscic 367:777-784

Policar T, Kozak P, Martin J (2006) Effects of egg bath and daily removal of dead eggs on hatching success and production of stage 2 juveniles during artificial incubation in noble crayfish (Astacus astacus). Bull Fr Pêche Piscic 381:1197-1206

Policar T, Smyth J, Flanigan M, Kouba A, Kozák P (2011) Sodium chloride as effective antifungal treatment for artificial egg incubation in Austropotamobius pallipes. Knowl Manag Aquat Ecosyst 401:13-24

Quaglio F, Morolli C, Galuppi R, Bonoli C, Marcer F, Nobile L, De Luise G, Tampieri MP (2006) Preliminary investigations of disease-causing organism in the white-clawed crayfish Austropotamobius Pallipes complex from streams of northern Italy. Bull Fr Pêche Piscic 381:1271-1290

Quaglio F, Galuppi F, Capovilla P, Santoro D, Bonoli C, Tampieri MP, Marcer F, Fioretto B (2008) Saprolegniaceae infection in white-clawed crayfish, Austropotamobius pallipes complex, in an experimental hatchery in Northern Italy. Ittiopatologia 5:19-33 [In Italian with English abstract]

Sáez-Royuela M, Melendre PM, Celada JD, Carral JM, González A, González R, García V (2009) Possibilities of artificial incubation of signal crayfish (Pacifastacus leniusculus Dana) eggs at high densities and reduced flow rate using formaldehyde as antifungal treatment. Aquaculture 288:65-68

Vedia I, Miranda R (2013) Review of the state of knowledge of crayfish species in the Iberian Peninsula. Limnetica 32(2):269-286

Venables WN, Ripley BD (2002) Modern applied statistics with S, Fourth edn. Springer, New York 495p 